\title{
Efektivitas Pemanfaatan Aplikasi Whatsapp Sebagai Media Komunikasi Penunjang Kinerja pada Karyawan PT. Flexindo
}

The Effectiveness of Whatsapp as a Medium to Support the Performance of PT. Flexindo Employees

Supriyanto
Danang Trijayanto
Program Studi Ilmu Komunikasi, Universtas 17 Agustus 1945 Jakarta,
Jalan Sunter Permai Raya, Sunter Agung Podomoro Jakarta Utara, 14350
y2980819@gmail.com, danang.trijayanto@uta45jakarta.ac.id

Dikirim: 23 Juni 2021, Direvisi: 25 Juni 2021, Diteriaa: 25 Juni 2021, Terbit: 30 Juni 202.

Sitasi: Supriyanto, Trijayanto. D, (2021)., Efektivitas Pemanfaatan Aplikasi Whatsapp Sebagai Media Komunikasi Penunjang Kinerja pada Karyawan PT. Flexindo, PRoMEDIA. Volume 7 (1), Juni 2021, hal 42- hal 78.

\begin{abstract}
The research objective was to determine the effectiveness of using the WhatsApp aplication in thw work environment, especially in the work of PT. Flexindo. In this research, there are variables studied, namely the independent variable $(X)$, namely the WhatsApp aolication and the dependent variable $(Y)$, namely the performance of the employees of PT.Flexindo, with the following variable details: Intensity, Communication and Satisfaction. Data collection methods used Survey methods and Census technique on 50 respondent. The result of the analysis is that effectiveness of using the WhatsApp aplication as a communication medium to support performance among employees of PT.Flexindo is very effective.
\end{abstract}

Keywords: Whatsapp, Performance, Employees, Flexindo. 
PT. Flexindo. Pada penelitian yang dilakukan ini, terdapat variabel yang diteliti yaitu variabel bebas (X) yaitu aplikasi whatsapp dan variabel terikat (Y) yaitu kinerja karyawan PT. Flexindo., dengan rincian variabel sebagai berikut: Intensitas, Komunikasi dan Kepuasan. Metode pengumpulan data yang digunakan adalah dengan menggunakan metode survei dan teknik sensus pada 50 Karyawan Flexindo. Hasii analisis bahwa Efektivitas pemanfaatan aplikasi whatsapp sebagai media komunikasi penunjang kinerja di kalangan karyawan PT. Flexindo adalah Sangat Efektif.

\section{Kata Kunci: Whatsapp, Kinerja, Karyawan, Flexindo}

\section{PENDAHULUAN}

Saat ini, Handphone yang merupakan salah satu bentuk teknologi komunikasi tidak hanya berfungsi sebagai alat untuk menelpon maupun mengirim pesan, tetapi telah berkembang menjadi teknologi yang lebih canggih dengan adanya aplikasi-aplikasi terbaru yang sengaja diciptakan untuk memudahkan komunikasi antar manusia. Perkembangan teknologi seperti ini telah memberikan warna-warna baru yang melengkapi kecanggihan handphone masa kini, yang kemudian lebih dikenal oleh masyarakat dengan sebutan smartphone (telepone pintar).

Berkembangnya teknologi yang semakin pesat tersebut dimanfaatkan oleh berbagai elemen masyarakat. Penelitian yang membahas mengenai pemanfaatan aplikasi whatsapp sebagai media komunikasi dan kepuasan dalam penyampaian pesan dikalangan tokoh masyarakat, didapati hasil penelitian bahwa aplikasi whatsapp dimanfaatkan oleh tokoh masyarakat untuk berkomunikasi dalam menyampaikan pesan kepada sasarannya, informasi yang disampaikan lebih efektif dan merupakan kepuasan tersendiri karena pesan lebih cepat 
diterima kepada sasaran (Trisnani, 2017). Whatsapp sebagai salah satu media sosial saat ini banyak digunakan untuk kepentingan bersosialisasi maupun sebagai penyampaian pesan baik oleh individu ke individu, individu ke kelompok, maupun kelompok ke kelompok, baik pemanfaatan secara formal ataupun informal. Bahkan pemanfaatan media whatsapp tersebut dimanfaatkan sampai ke lini dunia kerja, baik pemanfaatan secara formal untuk urusan pekerjaan maupaun secara informal yang penggunaannya untuk urusan pribadi.

Permasalahan sosialisasi dan koordinasi menjadi dapat menjadi hambatan karena pola komunikasi yang terjadi. Seperti Dalam proses publikasi humas BNPP, hambatannya terletak pada Komunikasi Vertikal antara Pimpinan dan Staff dalam proses publikasinya (Baskara, dkk, 2019).

Pemanfaatan aplikasi whatsapp di dunia kerja dinilai efektif. Penelitian yang menganalisis pengaruh komunikasi melalui grup whatsapp untuk meningkatkan kinerja karyawan di Hotel Grandhika Setiabudi Medan, secara keseluruhan menunjukkan bahwa terdapat pengaruh komunikasi melalui grup whatsapp untuk meningkatkan kinerja karyawan (Sihombing, dkk, .

WhatsApp merupakan aplikasi berbasis internet yang memungkinkan setiap penggunanya dapat saling berbagi berbagai macam konten sesuai dengan fitur pendukungnya. WhatsApp juga memiliki berbagai fitur yang dapat digunakan untuk berkomunikasi dengan bantuan layanan internet (Jumiatmoko, 2016). Sependapat dengan Jumiatmoko, menurut Pranajaya dan Hendra Wicaknono, WhatsApp merupakan media sosial paling populer yang dapat digunakan sebagai media komunikasi. Umumnya para pengguna WhatsApp menyebutkan alasan memilih aplikasi ini adalah karena tersedianya 
berbagai kemudahan yang ada di dalamnya di samping tidak mengeluarkan biaya alias gratis (Pranajaya \& Hendra Wicaksono, 2017).

Fitur-fitur yang terdapat dalam Whatsapp saat ini juga lumayan lengkap untuk ukuran aplikasi chat, yaitu seperti Gallery untuk menambahkan atau menyimpan foto dan video, contact untuk menyisipkan kontak nomor telepon, camera untuk mengambil gambar dan merekam video, audio untuk mengirim pesan suara dan melakukan panggilan suara, video sebagai salah satu fasilitas dari whatsapp yang bisa digunakan oleh pemgguna untuk melakukan panggilan video, maps untuk mengirimkan berbagai koordinat peta, fitur story atau status yang berguna untuk mengupdate status agar dapat dilihat oleh nomor orangorang yang tersimpan di kontak telepon, bahkan document untuk menyisipkan file berupa dokumen. Semua file tersebut dapat dalam sekejap dikirim melaui aplikasi gratis tersebut. Berbagai fitur tersebut tentu semakin menambah kemudahan dan kenyamanan berkomunikasi melalui media online (Jumiatmoko, 2016).

Seiring perkembangan teknologi dan didukung beberapa faktor, menjadikan whatsapp sebagai media sosial yang banyak digunakan juga dalam dunia kerja. Kemudahan dalam penggunaan, tampilan yang bersahabat, aplikasi yang gratis, ruang komunikasi yang menyediakan privasi bagi pengguna, panggilan suara ke sesama pengguna whatsapp yang gratis, penggunaan video call ke sesama pengguna whatsapp yang gratis pula dan keterbukaan saat berdiskusi di grub, menjadikan pengguna whatsapp makin betah dalam menggunakan aplikasi tersebut.

Dikutip dari kompas tekno, CEO Facebook, Mark Zuckerberg belakangan mengumumkan bahwa kini aplikasi WhatsApp telah menembus angka dua miliar pengguna secara global. Meski demikian, Zuckerberg tidak menjabarkan secara detail mengenai pertumbuhan 
penggunanya. Total keseluruhan pesan yang dikirimkan oleh pengguna aktif melalui aplikasi WhatsApp dilaporkan mencapai 100 miliar pesan setiap harinya.

(sumber:https://tekno.kompas.com/read/2020/11/01/16030007/whatsap p-saat-ini-2-miliar-pengguna-100-miliar-pesan-per-hari).

Hasil penelitian yang dilakukan oleh Raharti pada 2019 dengan judul penelitian Whatsapp media komunikasi efektif masa kini (studi kasus pada layanan jasa informasi ilmiah di kawasan puspitek). Disimpulkan Whatsapp adalah media komunikasi efektif masa kini yang paling banyak digunakan oleh pemustaka di kawasan Puspiptek ketika membutuhkan layanan jasa informasi. (Raharti, 2019).

Melihat kondisi dilapangan khususnya lingkungan kerja PT. Flexindo, semua karyawannya menggunakan aplikasi whatsapp khususnya di jam kerja hari senin sampai jumat, yang dimulai dari pukul 09:00 WIB sampai 16:00 WIB. Melihat kondisi tersebut, penulis ingin tahu lebih mendalam mengenai pemanfaatan aplikasi whatsapp di dunia kerja khususnya di lingkungan kerja PT. Flexindo.

Komunikasi ini digunakan untuk menyelesaikan setiap permasalahan yang berurusan dengan konsumen atau pelanggan. Komunikasi dan koordinasi melalui media whatsapp menjadi bagian untuk meningkatkan kualitas layanan. Kualitas pelayanan tentu berpengaruh pada loyalitas pelanggan (Sugiarsih, 2019)

PT. Flexindo merupakan perusahaan yang bergerak di bidang layanan telekomunikasi. Dengan kantor pusat yang berada di Jl. Gading Kirana Utara Nomor 30 Kelapa Gading Jakarta Utara. Perusahaan tersebut sudah bergerak di bidang telekomunikasi sejak tahun 2011. PT. Flexindo memiliki nama lengkap PT. Flexindo Mandiri Utama atau biasa disingkat FMU, yang merupakan bagian dari Smartcom Group. 
Flexindo yang berasal dari kata "Flexibel" berarti selalu berusaha untuk beradaptasi dengan teknologi telekomunikasi terkini sehingga kami selalu memberikan nilai lebih di dunia telekomunikasi Indonesia. Kami menyediakan fasilitas alat untuk menghemat biaya komunikasi International, interlokal dan selular dengan sistem telekomunikasi berbasiskan IP (Internet Protocol) pada operator GSM didukung oleh provider terbesar yaitu PT. Telekomunikasi Indonesia.

Tujuan dari FMU ialah memberikan solusi terbaik untuk menurunkan biaya pemakaian komunikasi telepon pelanggan, sehingga dengan layanan ini biaya percakapan menjadi lebih murah terutama percakapan Interlokal SLJJ, Selular bahkan Internasional, dengan tidak mengesampingkan kualitas suara.

PT. Flexindo Mandiri Utama bekerja sama dengan Operator terbesar di Indonesia yaitu PT. Telekomunikasi Indonesia (Telkom) dan operator lain seperti Telkomsel, Indosat, Three, Smartfren. Selain itu FMU juga bekerja sama dengan operator internet seperti Biznet, CBN, Indihome, Velo networks. FMU Solution untuk menekan biaya dengan menggunakan telepon telekomunikasi berbasis FWT (Fixed Wireless Terminal), FWP (Fixed Wireless Phone) atau menggunakan IP (Internet Protocol).

Memberikan solusi terbaik untuk menekan biaya komunikasi telepon pelanggan, sehingga dengan adanya layanan ini maka panggilan menjadi lebih murah khususnya percakapan Internasional, SLJJ dan Handphone. FMU memberikan "Total Solution" bagi klien yang mengalami kesulitan dalam mengembangkan hubungan bisnis dengan pelanggannya melalui komunikasi telepon dengan biaya yang sangat terjangkau, Call Detail Record (CDR) yang lengkap meliputi nomor tujuan, tanggal dan waktu pemakaian, durasi percakapan, Tarif Reguler 
Sebagai Tarif perbandingan serta persentase penghematan yang di dapat.

Flexindo menyiapkan Layanan NOC yang siap melayanin 7 x 24 jam, jadi pelanggan tidak perlu khawatir jika sewaktu-waktu mengalami kendala atau jika ingin mendapatkan informasi lebih lanjut terkait PT. Flexindo. Selain itu untuk biaya maintenance juga gratis, dan adanya penjadwalan rutin teknisi ke pelanggan untuk pengecekan rutin perangkat dan jaringan telepon. Agar meminimalisir adanya gangguan dan penanganan yang lebih awal jika ada gangguan yang terjadi.

Lalu dengan berbagai fitur dan kemudahan yang dihadirkan oleh aplikasi whatsapp, apakah membawa dampak yang signifikan untuk menunjang kinerja karyawan? dan bagaimana pemanfaatan aplikasi whatsapp dalam proses komunikasi antar karyawan di lingkungan kerja PT. Flexindo ? sehingga semua karyawan menggunaan aplikasi whatsapp. Penelitian bertujuan untuk memahami bagaimana efektivitas pemanfaatan aplikasi whatsapp dalam dunia kerja, khususnya pada karyawan PT. Flexindo sebagai media komunikasi penunjang kinerja. Fenomena yang dijadikan bahan penelitian ini (SME, 2020)

\section{TINJAUAN PUSTAKA}

Beberapa penelitian yang berkaitan dengan efektivitas Whatsapp dilihat dalam beberapa penelitian. Penggunaan media komunikasi whatsapp terbukti mempengaruhi kinerja karyawan (Andjani, dkk, 2018). Penelitian yang dilakukan oleh Raharti pada VISI PUSTAKA Vol. 21, No. 2, Agustus 2019. Judul penelitian: "Whatsapp Media Komunikasi Efektif Masa Kini (Studi Kasus Pada Layanan Jasa Informasi Ilmiah Di Kawasan PUSPIPTEK). Penelitian ini bertujuan: (1) Mengetahui sejauh mana aplikasi WhatsApp digunakan sebagai media komunikasi pada layanan jasa 
informasi; (2) Mengetahui alasan pemustaka lebih suka menggunakan whatsApp dibanding media komunikasi lainnya. Digunakan metode deskriptif kuantitatif untuk memberikan fakta dan data mengenai media komunikasi yang digunakan pada layanan jasa informasi di Kawasan Puspiptek. Hasil penelitian menunjukkan selama 3 tahun terakhir (tahun 2016-2018) Disimpulkan WhatsAppp adalah media komunikasi efektif masa kini yang paling banyak digunakan oleh pemustaka di kawasan Puspiptek ketika membutuhkan layanan jasa informasi.

Penelitian yang yang dilakukan oleh Trisnani pada JURNAL KOMUNIKASI, MEDIA DAN INFORMATIKA Volume 6 Nomor 3/ November 2017. Judul penelitiannya adalah Pemanfaatan Whatsapp Sebagai Media Komunikasi dan Kepuasan dalam Penyampaian Pesan di kalangan Tokoh Masyarakat. Penelitian tersebut menggunakan metode desktiptif didukung dengan wawancara mendalam. Hasilnya, Whatsapp telah dimanfaatkan oleh tokoh masyarakat untuk berkomunikasi dalam menyampaikan pesan kepada sasarannya. Saat ini meskipun masih berkomunikasi secara langsung, Tokoh masyarakat memanfaatkan Whatsapp sebagai media komunikasi dalam menyampaikan pesan. informasi yang disampaikan lebih efektif dan merupakan kepuasan tersendiri karena menggunakan teknologi informasi (Whatsapp) pesan lebih cepat diterima kepada sasaran. Penelitian yang dilakukan oleh Mega Ulva Sari Sihombing dan Arifin Sugianto, dengan judul penelitian Pengaruh Komunikasi Melalui Grup 
WhatsApp Untuk Meningkatkan Kinerja Karyawan di Hotel Grandhika Medan. Penelitian tersebut bertujuan untuk menganalisis pengaruh komunikasi melalui grup whatsapp untuk meningkatkan kinerja karyawan di Hotel GrandhikaSetiabudi Medan. Teori yang yang digunakan dalam penelitian ini adalah Teori S-O-R (Stimulus-Organism-Response), dimana Stimulusnya adalah pengaruh komunikasi melalui grup whatsapp,Organismnya adalah karyawan di Hotel Grandhika Setiabudi Medan, dan Responsenya adalah Kinerja. Penelitian tersebut menggunakan metode korelasional, yaitu metode yang bertujuan meneliti sejauh mana variasi pada suatu faktor berkaitan dengan faktor lain. Metode penelitian tersebut digunakan untuk menemukan ada tidaknya pengaruh antar variabel dan apabila ada, seberapa besar eratnya hubungan serta berarti atau tidaknya hubungan tersebut. Hasil keseluruhan penelitiannya menunjukkan bahwa terdapat pengaruh komunikasi melalui grup whatsapp untuk meningkatkan kinerja karyawan di Hotel Grandhika Setiabudi Medan. Pengaruh tersebut merupakan hubungan yang cukup berarti. Hasil yang bertolak belakang terjadi pada kinerja pegawai kantor Kesehatan pelabuhan kelas I Medan, yaitu penggunaan WhatsApp telah berdampak negatif terhadap kinerja pegawai, artinya semakin intensif penggunaan WA maka kinerja pegawai semakin rendah dan sebaliknya semakin rendah penggunaan WA maka kinerja pegawai akan semakin tinggi (Parinduri, 2019). 


\section{METODOLOGI PENELITIAN}

Metode pengumpulan data yang digunakan adalah dengan menggunakan metode survei. Penelitian ini adalah penelitian deskriptif. Uji validitas dapat dilakukan dengan menggunakan korelasi product moment, yaitu mengkorelasikan skor masing-masing item dengan skor total. uji reliabilitas dengan menggunakan metode Alpha Cronbach. Populasi digunakan untuk menyebutkan seluruh elemen/anggota dari suatu wilayah yang menjadi sasaran penelitian atau merupakan keseluruhan (universum) dari objek penelitian (Noor, 2012).

Populasi merupakan objek atau subjek yang berada pada suatu wilayah dan memenuhi syarat-syarat tertentu berkaitan dengan masalah penelitian. Adapun populasi dalam penelitian ini adalah seluruh karyawan PT. Flexindo yang berjumlah 50 orang. Pengambilan sample dengan sampling jenuh atau sensus. Sampling jenuh atau sensus adalah teknik penentuan sampel bila semua anggota populasi digunakan sebagai sampel Menurut (Sugiyono, 2008). Istilah lain sampling jenuh adalah sensus, sehingga objek yang diteliti seluruh karyawan PT. Flexindo yang berjumlah 50 orang.

Dalam penelitian ini, skala pengukuran yang digunakan ialah skala Likert. Rentang skala Likert yang dipakai dalam penelitian ini adalah 1 hingga 5, maka rentang skala penilaian yang didapat adalah:

$$
\mathrm{Rs}=\frac{5-1}{5}=0,8
$$

Sehingga posisi keputusannya menjadi 


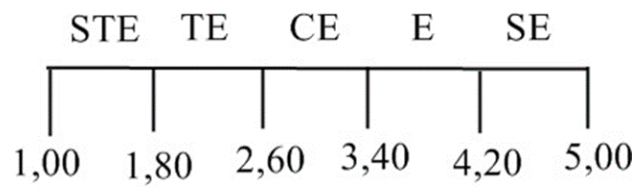

Keterangan :

STE : Sangat Tidak Efektiv (masuk skala 1,00-1,80)

TE : Tidak Efektif (masuk skala 1,80-2,60)

CE : Cukup Efektif (masuk skala 2,60-3,40)

E : Efektif (masuk skala 3,40-4,20)

SE : Sangat Efektif (masuk skala 4,20-5,00)

Sehingga setiap elemen Efektivitas Pemanfaatan Aplikasi Whatsapp Sebagai Media Komunikasi Penunjang Kinerja di Kalangan Karyawan PT. Flexindo akan diukur dan dianalisis kemudian dimasukkan dalam rentang skala dari yang sangat tidak efektif (STE) sampai dengan sangat efektif (SE).

Konsep yang diukur dalam penelitian ini adalah Efektivitas media Whatsapp. Pengertian Efektivitas merupakan daya pesan untuk mempengaruhi atau tingkat kemampuan pesan-pesan untuk mempengaruhi (Susanto, 1975). Keefektivan pertukaran pesan dapat dilihat dari beberapa hal, yaitu:
a. Intensitas
b. Komunikasi
c. Kepuasan

\section{PEMBAHASAN}

\section{A. Intensitas}

\section{Penggunaan Aplikasi Whatsapp}


Tabel 1. Frekuensi Persentase

\begin{tabular}{|c|l|c|c|}
\hline Pertanyaan & \multicolumn{1}{|c|}{ Item } & Frekuensi & Persentase \\
\hline \multirow{5}{*}{$\begin{array}{l}\text { 1. Saya sering } \\
\text { menggunakan } \\
\text { Aplikasi Whatsapp }\end{array}$} & Setuju & 25 & $50,00 \%$ \\
\cline { 2 - 4 } & $\begin{array}{l}\text { Sangat } \\
\text { Setuju }\end{array}$ & 23 & $46,00 \%$ \\
\cline { 2 - 4 } & $\begin{array}{l}\text { Tidak } \\
\text { Setuju }\end{array}$ & 0 & $0,00 \%$ \\
\cline { 2 - 4 } & $\begin{array}{l}\text { Sangat } \\
\text { Tidak } \\
\text { Setuju }\end{array}$ & 0 & $0,00 \%$ \\
\cline { 2 - 4 } & Netral & 2 & $4,00 \%$ \\
\hline \multicolumn{2}{|c|}{ Sangat Efektif } & 50 & $100,00 \%$ \\
\hline
\end{tabular}

Sumber: Data peneliti Kuesioner nomor 1

Pernyataan "Saya sering menggunakan Aplikasi Whatsapp" didapatkan data: 25 responden menjawab setuju dengan persentase $50,00 \%, 23$ responden menjawab sangat setuju dengan persentase $46,00 \%$, untuk pilihan jawaban tidak setuju dan sangat tidak setuju tidak ada responden yang memilih sehingga persentase masing-masing ialah $0,00 \%$, dan sebanyak 2 responden menjawab netral dengan besaran persentase 4,00\%. Dari pernyataan kuesioner nomor 1, mendapatkan hasil 50 responden yang menjawab dengan persentase $100 \%$. Skor rata-rata:

$$
\begin{aligned}
X_{(1)} & =\frac{(23 \times 5)+(25 \times 4)+(2 \times 3)+(0 \times 2)+(0 \times 1)}{50} \\
& =4,42
\end{aligned}
$$

Hasil yang didapat dari kuesioner nomor 1 ialah 4,42 yang artinya dapat disimpulkan bahwa pada elemen kuesioner nomor 1 tersebut, yaitu pada tingkat penggunaan aplikasi whatsapp dapat disimpulkan Sangat Efektif.

\section{Keaktifan Memanfaatkan Aplikasi Whatsapp}


Tabel 2. Peran aktif dalam memanfaatkan aplikasi whatsApp

\begin{tabular}{|c|c|c|c|}
\hline Pertanyaan & Item & Frekuensi & Persentase \\
\hline \multirow{5}{*}{$\begin{array}{l}\text { 2. Saya berperan } \\
\text { aktif dalam } \\
\text { memanfaatkan } \\
\text { Whatsapp }\end{array}$} & Setuju & 29 & $58,00 \%$ \\
\hline & $\begin{array}{l}\text { Sangat } \\
\text { Setuju }\end{array}$ & 16 & $32,00 \%$ \\
\hline & $\begin{array}{l}\text { Tidak } \\
\text { Setuju }\end{array}$ & 0 & $0,00 \%$ \\
\hline & $\begin{array}{l}\text { Sangat } \\
\text { Tidak } \\
\text { Setuju }\end{array}$ & 0 & $0,00 \%$ \\
\hline & Netral & 5 & $10,00 \%$ \\
\hline \multicolumn{2}{|c|}{ Sangat Efektif } & 50 & $100,00 \%$ \\
\hline
\end{tabular}

Sumber: Data peneliti Kuesioner nomor 2

Pernyataan "Saya berperan aktif dalam memanfaatkan Whatsapp" didapatkan data: 29 responden menjawab setuju dengan persentase 58,00\%, 16 responden menjawab sangat setuju dengan persentase $32,00 \%$, untuk pilihan jawaban tidak setuju dan sangat tidak setuju tidak ada responden yang memilih sehingga persentase masing-masing ialah $0,00 \%$, dan sebanyak 5 responden menjawab netral dengan persentase 10,00\%. Dari pernyataan kuesioner nomor 2, mendapatkan hasil 50 responden yang menjawab dengan persentase $100 \%$. Skor rata-rata:

$$
\begin{aligned}
X_{(2)} & =\frac{(16 \times 5)+(29 \times 4)+(5 \times 3)+(0 \times 2)+(0 \times 1)}{50} \\
& =4,22
\end{aligned}
$$

Hasil yang didapat dari kuesioner nomor 2 ialah 4,22 yang artinya dapat disimpulkan bahwa pada elemen kuesioner nomor 2 tersebut, yaitu pada tingkat Peran aktif dalam 
memanfaatkan aplikasi whatsApp dapat disimpulkan Sangat Efektif.

\section{Penggunaan Aplikasi Whatsapp Pada Waktu Kerja}

Tabel 3. Penggunaan aplikasi whatsapp pada waktu

kerja

\begin{tabular}{|c|c|c|c|}
\hline Pertanyaan & Item & Frekuensi & Persentase \\
\hline \multirow{5}{*}{$\begin{array}{l}\text { 3. Saya } \\
\text { menggunakan } \\
\text { Whatsapp } \\
\text { pada hari dan } \\
\text { waktu kerja }\end{array}$} & Setuju & 27 & $54,00 \%$ \\
\hline & $\begin{array}{l}\text { Sangat } \\
\text { Setuju }\end{array}$ & 22 & $44,00 \%$ \\
\hline & $\begin{array}{l}\text { Tidak } \\
\text { Setuju }\end{array}$ & 0 & $0,00 \%$ \\
\hline & $\begin{array}{l}\text { Sangat } \\
\text { Tidak } \\
\text { Setuju }\end{array}$ & 1 & $2,00 \%$ \\
\hline & Netral & 0 & $0,00 \%$ \\
\hline \multicolumn{2}{|c|}{ Sangat Efektif } & 50 & $100,00 \%$ \\
\hline
\end{tabular}

Sumber: Data peneliti Kuesioner nomor 3

Pernyataan "Saya menggunakan Whatsapp pada hari dan waktu kerja" didapatkan data: 27 responden menjawab setuju dengan persentase 54,00\%, 22 responden menjawab sangat setuju dengan persentase $44,00 \%$, tidak ada responden yang memilih pada jawaban tidak setuju dan netral sehingga persentasenya $0,00 \%, 1$ responden menjawab sangat tidak setuju dengan persentase 2,00\%. Dari pernyataan kuesioner nomor 3, mendapatkan hasil 50 responden yang menjawab dengan persentase $100 \%$.

Skor rata-rata:

$$
\begin{aligned}
X_{(3)} & =\frac{(22 \times 5)+(27 \times 4)+(0 \times 3)+(0 \times 2)+(1 \times 1)}{50} \\
& =4,38
\end{aligned}
$$


Hasil yang didapat dari kuesioner nomor 3 ialah 4,38 yang artinya dapat disimpulkan bahwa pada elemen kuesioner nomor 3 tersebut, yaitu pada tingkat Penggunaan aplikasi whatsapp pada waktu kerja dapat disimpulkan Sangat Efektif

\section{Intensitas Waktu Penggunaan Aplikasi Whatsapp}

Tabel 4. Intensitas waktu penggunaan aplikasi

whatsapp

\begin{tabular}{|c|c|c|c|}
\hline Pertanyaan & Item & Frekuensi & Persentase \\
\hline \multirow{5}{*}{$\begin{array}{l}\text { 4. Dalam } \\
\text { sehari, saya } \\
\text { menggunakan } \\
\text { Whatsapp } \\
\text { lebih dari } 8 \\
\text { jam }\end{array}$} & Setuju & 24 & $48,00 \%$ \\
\hline & $\begin{array}{l}\text { Sangat } \\
\text { Setuju }\end{array}$ & 14 & $28,00 \%$ \\
\hline & $\begin{array}{l}\text { Tidak } \\
\text { Setuju }\end{array}$ & 7 & $14,00 \%$ \\
\hline & $\begin{array}{l}\text { Sangat } \\
\text { Tidak } \\
\text { Setuju } \\
\end{array}$ & 0 & $0,00 \%$ \\
\hline & Netral & 5 & $10,00 \%$ \\
\hline \multicolumn{2}{|c|}{ Efektif } & 50 & $100,00 \%$ \\
\hline
\end{tabular}

Sumber: Data peneliti Kuesioner nomor 4

Pernyataan "Dalam sehari, saya menggunakan Whatsapp lebih dari 8 jam" didapatkan data: 24 responden menjawab setuju dengan persentase 48,00\%, 14 responden menjawab sangat setuju dengan persentase $28,00 \%, 7$ responden menjawab tidak setuju dengan persentase $14,00 \%$, tidak ada responden yang memilih pada jawaban sangat tidak setuju sehingga persentasenya $0,00 \%, 5$ responden menjawab netral dengan persentase $10,00 \%$. Dari pernyataan kuesioner nomor 4, mendapatkan hasil 50 responden yang menjawab dengan persentase $100 \%$. Skor rata-rata: 


$$
\begin{aligned}
X_{(4)} & =\frac{(14 \times 5)+(24 \times 4)+(5 \times 3)+(7 \times 2)+(0 \times 1)}{50} \\
& =3,9
\end{aligned}
$$

Hasil yang didapat dari kuesioner nomor 4 ialah 3,9 yang artinya dapat disimpulkan bahwa pada elemen kuesioner nomor 4 tersebut, yaitu pada tingkat Intensitas waktu penggunaan aplikasi whatsapp dapat disimpulkan Efektif.

\section{Penggunaan Aplikasi Whatsapp dalam Urusan Kerja}

Tabel 5. Penggunaan aplikasi whatsapp dalam urusan

\begin{tabular}{|c|c|c|c|}
\hline Pertanyaan & Item & Frekuensi & Persentase \\
\hline \multirow{5}{*}{$\begin{array}{l}\text { 5. Saya selalu } \\
\text { menggunakan } \\
\text { Whatsapp } \\
\text { dalam urusan } \\
\text { kerja }\end{array}$} & Setuju & 30 & $60,00 \%$ \\
\hline & $\begin{array}{l}\text { Sangat } \\
\text { Setuju }\end{array}$ & 19 & $38,00 \%$ \\
\hline & $\begin{array}{l}\text { Tidak } \\
\text { Setuju }\end{array}$ & 1 & $2,00 \%$ \\
\hline & $\begin{array}{l}\text { Sangat } \\
\text { Tidak } \\
\text { Setuju } \\
\end{array}$ & 0 & $0,00 \%$ \\
\hline & Netral & 0 & $0,00 \%$ \\
\hline \multicolumn{2}{|c|}{ Sangat Efektif } & 50 & $100,00 \%$ \\
\hline
\end{tabular}

kerja

Sumber: Data peneliti Kuesioner nomor 5

Pernyataan "Saya selalu menggunakan Whatsapp dalam urusan kerja" didapatkan data: 30 responden menjawab setuju dengan persentase $60,00 \%, 19$ responden menjawab sangat setuju dengan persentase $38,00 \%, 1$ responden menjawab tidak setuju dengan persentase $2,00 \%$, dan pada pilihan jawaban sangat tidak setuju dan netral tidak ada responden yang memilih jawaban tersebut, sehingga persentasenya 0,00\%. Dari pernyataan kuesioner nomor 5, mendapatkan 
hasil 50 responden yang menjawab dengan persentase $100 \%$.

Skor rata-rata:

$$
\begin{aligned}
X_{(5)} & =\frac{(19 \times 5)+(30 \times 4)+(0 \times 3)+(1 \times 2)+(0 \times 1)}{50} \\
& =4,34
\end{aligned}
$$

Hasil yang didapat dari kuesioner nomor 5 ialah 4,34 yang artinya dapat disimpulkan bahwa pada elemen kuesioner nomor 5 tersebut, yaitu pada tingkat Penggunaan aplikasi whatsapp dalam urusan kerja dapat disimpulkan Sangat Efektif.

\section{Aplikasi Whatsapp Bermanfaat Bagi Pengguna}

\begin{tabular}{|c|c|c|c|}
\hline Pertanyaan & Item & Frekuensi & Persentase \\
\hline \multirow{5}{*}{$\begin{array}{l}\text { 6. Whatsapp } \\
\text { memberikan } \\
\text { manfaat } \\
\text { untuk saya }\end{array}$} & Setuju & 28 & $56,00 \%$ \\
\hline & $\begin{array}{l}\text { Sangat } \\
\text { Setuju }\end{array}$ & 22 & $44,00 \%$ \\
\hline & $\begin{array}{l}\text { Tidak } \\
\text { Setuju }\end{array}$ & 0 & $0,00 \%$ \\
\hline & $\begin{array}{l}\text { Sangat } \\
\text { Tidak } \\
\text { Setuju } \\
\end{array}$ & 0 & $0,00 \%$ \\
\hline & Netral & 0 & $0,00 \%$ \\
\hline \multicolumn{2}{|c|}{ Sangat Efektif } & 50 & $100,00 \%$ \\
\hline
\end{tabular}

Tabel 6. Manfaat aplikasi whatsapp untuk pengguna

Sumber: Data peneliti Kuesioner nomor 6

Pernyataan "Whatsapp memberikan manfaat untuk saya" didapatkan data: 28 responden menjawab setuju dengan persentase 56,00\%, 22 responden menjawab sangat setuju dengan persentase $44,00 \%$, dan tidak ada responden yang memilih pada pilihan jawaban tidak setuju, sangat tidak setuju dan netral, sehingga persentasenya $0,00 \%$. Dari pernyataan kuesioner nomor 6 , mendapatkan hasil 50 responden yang 
menjawab dengan persentase $100 \%$. Skor rata-rata:

$$
\begin{aligned}
X_{(6)} & =\frac{(22 \times 5)+(28 \times 4)+(0 \times 3)+(0 \times 2)+(0 \times 1)}{50} \\
& =4,44
\end{aligned}
$$

Hasil yang didapat dari kuesioner nomor 6 ialah 4,44 yang artinya dapat disimpulkan bahwa pada elemen kuesioner nomor 6 tersebut, yaitu pada tingkat Manfaat aplikasi whatsapp untuk pengguna dapat disimpulkan Sangat Efektif.

\section{B. KOMUNIKASI}

\section{Penggunaa Aplikasi Whatsapp Untuk Berkomunikasi}

Tabel 7. Penggunaan aplikasi whatsapp untuk

\begin{tabular}{|c|c|c|c|}
\hline Pertanyaan & Item & Frekuensi & Persentase \\
\hline \multirow{5}{*}{$\begin{array}{l}\text { 7. Saya } \\
\text { menggunakan } \\
\text { Whatsapp } \\
\text { untuk } \\
\text { berkomunikasi } \\
\text { dengan rekan } \\
\text { kerja }\end{array}$} & Setuju & 32 & $64,00 \%$ \\
\hline & $\begin{array}{l}\text { Sangat } \\
\text { Setuju }\end{array}$ & 18 & $36,00 \%$ \\
\hline & $\begin{array}{l}\text { Tidak } \\
\text { Setuju }\end{array}$ & 0 & $0,00 \%$ \\
\hline & $\begin{array}{l}\text { Sangat } \\
\text { Tidak } \\
\text { Setuju }\end{array}$ & 0 & $0,00 \%$ \\
\hline & Netral & 0 & $0,00 \%$ \\
\hline \multicolumn{2}{|c|}{ Sangat Efektif } & 50 & $100,00 \%$ \\
\hline
\end{tabular}
berkomunikasi

Sumber: Data peneliti Kuesioner nomor 7

Pernyataan "Saya menggunakan Whatsapp untuk berkomunikasi dengan rekan kerja" didapatkan data: 32 responden menjawab setuju dengan persentase $64,00 \%, 18$ responden menjawab sangat setuju dengan persentase $36,00 \%$, dan tidak ada responden yang memilih pada pilihan jawaban tidak setuju, sangat tidak setuju dan netral, sehingga persentasenya $0,00 \%$. Dari pernyataan kuesioner nomor 7 , 
mendapatkan hasil 50 responden yang menjawab dengan persentase $100 \%$. Skor rata-rata:

$$
\begin{aligned}
X_{(7)} & =\frac{(18 \times 5)+(32 \times 4)+(0 \times 3)+(0 \times 2)+(0 \times 1)}{50} \\
& =4,36
\end{aligned}
$$

Hasil yang didapat dari kuesioner nomor 7 ialah 4,36 yang artinya dapat disimpulkan bahwa pada elemen kuesioner nomor 7 tersebut, yaitu pada tingkat Penggunaan aplikasi whatsapp untuk berkomunikasi dengan rekan kerja dapat disimpulkan Sangat Efektif.

\section{Pemanfaatan Aplikasi Whatsapp untuk Berikirim Lampiran}

Tabel 8. Pemanfaatan aplikasi whatsapp untuk berkirim pesan, file dokumen, gambar/ foto, audio, maupun

\begin{tabular}{|c|c|c|c|}
\hline Pertanyaan & Item & Frekuensi & Persentase \\
\hline \multirow{5}{*}{$\begin{array}{l}\text { 8. Saya } \\
\text { memanfaatkan } \\
\text { Whatsapp untuk } \\
\text { berkirim pesan, } \\
\text { file dokumen, } \\
\text { gambar/foto, } \\
\text { audio, maupun } \\
\text { video }\end{array}$} & Setuju & 25 & $50,00 \%$ \\
\hline & $\begin{array}{l}\text { Sangat } \\
\text { Setuju }\end{array}$ & 25 & $50,00 \%$ \\
\hline & $\begin{array}{l}\text { Tidak } \\
\text { Setuju } \\
\end{array}$ & 0 & $0,00 \%$ \\
\hline & $\begin{array}{l}\text { Sangat } \\
\text { Tidak } \\
\text { Setuju }\end{array}$ & 0 & $0,00 \%$ \\
\hline & Netral & 0 & $0,00 \%$ \\
\hline \multicolumn{2}{|c|}{ Sangat Efektif } & 50 & $100,00 \%$ \\
\hline
\end{tabular}
video

Sumber: Data peneliti Kuesioner nomor 8

Pernyataan "Saya memanfaatkan Whatsapp untuk berkirim pesan, file dokumen, gambar/foto, audio, maupun video" didapatkan data: 25 responden menjawab setuju 
dengan persentase $50,00 \%, 25$ responden menjawab sangat setuju dengan persentase $50,00 \%$, dan tidak ada responden yang memilih pada pilihan jawaban tidak setuju, sangat tidak setuju dan netral, sehingga persentasenya $0,00 \%$. Dari pernyataan kuesioner nomor 8 , mendapatkan hasil 50 responden yang menjawab dengan persentase $100 \%$.

Skor rata-rata:

$$
\begin{aligned}
X_{(8)} & =\frac{(25 \times 5)+(25 \times 4)+(0 \times 3)+(0 \times 2)+(0 \times 1)}{50} \\
& =4,5
\end{aligned}
$$

Hasil yang didapat dari kuesioner nomor 8 ialah 4,5 yang artinya dapat disimpulkan bahwa pada elemen kuesioner nomor 8 tersebut, yaitu pada tingkat Pemanfaatan aplikasi whatsapp untuk berkirim pesan, file dokumen, gambar/foto, audio, maupun video dapat disimpulkan Sangat Efektif.

\section{Penggunaan Aplikasi Whatsapp Untuk Bertukar Informasi Mengenai Urusan Pekerjaan}

Tabel 9. Pengguna bertukar informasi mengenai

\begin{tabular}{|c|c|c|c|}
\hline Pertanyaan & Item & Frekuensi & Persentase \\
\hline \multirow{5}{*}{$\begin{array}{l}\text { 9. Saya } \\
\text { bertukar } \\
\text { (mengirim } \\
\text { dan } \\
\text { mendapatkan) } \\
\text { informasi } \\
\text { mengenai } \\
\text { urusan } \\
\text { pekerjaan } \\
\text { dengan } \\
\text { menggunakan } \\
\text { Whatsapp }\end{array}$} & Setuju & 33 & $66,00 \%$ \\
\hline & $\begin{array}{l}\text { Sangat } \\
\text { Setuju }\end{array}$ & 17 & $34,00 \%$ \\
\hline & $\begin{array}{l}\text { Tidak } \\
\text { Setuju }\end{array}$ & 0 & $0,00 \%$ \\
\hline & $\begin{array}{l}\text { Sangat } \\
\text { Tidak } \\
\text { Setuju }\end{array}$ & 0 & $0,00 \%$ \\
\hline & Netral & 0 & $0,00 \%$ \\
\hline
\end{tabular}
urusan pekerjaan dengan aplikasi whatsapp 


\begin{tabular}{|r|r|r|}
\hline Sangat Efektif & 50 & $100,00 \%$ \\
\hline
\end{tabular} \\ Sumber: Data peneliti Kuesioner nomor 9}

Pernyataan "Saya bertukar (mengirim dan mendapatkan) informasi mengenai urusan pekerjaan dengan menggunakan Whatsapp" didapatkan data: 33 responden menjawab setuju dengan persentase $66,00 \%, 17$ responden menjawab sangat setuju dengan persentase $34,00 \%$, dan tidak ada responden yang memilih pada pilihan jawaban tidak setuju, sangat tidak setuju dan netral, sehingga persentasenya 0,00\%. Dari pernyataan kuesioner nomor 9, mendapatkan hasil 50 responden yang menjawab dengan persentase $100 \%$. Skor rata-rata:

$$
\begin{aligned}
X_{(9)} & =\frac{(17 \times 5)+(33 \times 4)+(0 \times 3)+(0 \times 2)+(0 \times 1)}{50} \\
& =4,34
\end{aligned}
$$

Hasil yang didapat dari kuesioner nomor 9 ialah 4,34 yang artinya dapat disimpulkan bahwa pada elemen kuesioner nomor 9 tersebut, yaitu pada tingkat Pengguna bertukar informasi mengenai urusan pekerjaan dengan aplikasi whatsapp dapat disimpulkan Sangat Efektif.

\section{Responsifitas Bagi Pengguna Ketika Bertanya Melalui Aplikasi Whatsapp}

Tabel 10. Pengguna mendapat respon ketika bertanya melalui aplikasi whatsapp

\begin{tabular}{|c|c|c|c|}
\hline Pertanyaan & Item & Frekuensi & Persentase \\
\hline & Setuju & 30 & $60,00 \%$ \\
\hline
\end{tabular}




\begin{tabular}{|c|c|c|c|}
\hline \multirow{4}{*}{$\begin{array}{l}\text { 10. Saya mendapat } \\
\text { tanggapan/jawaban } \\
\text { ketika bertanya } \\
\text { mengenai urusan } \\
\text { pekerjaan melalui } \\
\text { Whatsapp }\end{array}$} & $\begin{array}{l}\text { Sangat } \\
\text { Setuju }\end{array}$ & 18 & $36,00 \%$ \\
\hline & $\begin{array}{l}\text { Tidak } \\
\text { Setuju }\end{array}$ & 0 & $0,00 \%$ \\
\hline & $\begin{array}{l}\text { Sangat } \\
\text { Tidak } \\
\text { Setuju }\end{array}$ & 0 & $0,00 \%$ \\
\hline & Netral & 2 & $4,00 \%$ \\
\hline \multicolumn{2}{|c|}{ Sangat Efektif } & 50 & $100,00 \%$ \\
\hline
\end{tabular}

Sumber: Data peneliti Kuesioner nomor 10

Pernyataan "Saya mendapat tanggapan/ jawaban ketika bertanya mengenai urusan pekerjaan melalui Whatsapp" didapatkan data: 30 responden menjawab setuju dengan persentase $60,00 \%, 18$ responden menjawab sangat setuju dengan persentase $36,00 \%$, tidak ada responden yang memilih pada pilihan jawaban tidak setuju dan sangat tidak setuju, sehingga persentasenya $0,00 \%$, dan sebanyak 2 responden menjawab netral dengan persentase $4,00 \%$. Dari pernyataan kuesioner nomor 10, mendapatkan hasil 50 responden yang menjawab dengan persentase $100 \%$.

Skor rata-rata:

$$
\begin{aligned}
X_{(10)} & =\frac{(18 \times 5)+(30 \times 4)+(2 \times 3)+(0 \times 2)+(0 \times 1)}{50} \\
& =4,32
\end{aligned}
$$

Hasil yang didapat dari kuesioner nomor 10 ialah 4,32 yang artinya dapat disimpulkan bahwa pada elemen kuesioner nomor 10 tersebut, yaitu pada tingkat Pengguna mendapat respon / tanggapan ketika bertanya mengenai urusan pekerjaan melalui aplikasi whatsapp dapat disimpulkan Sangat Efektif. 


\section{Peran Aktif Pengguna Saat Berdiskusi Di Aplikasi Whatsapp}

Tabel 11. Peran aktif pengguna saat berdiskusi di aplikasi whatsapp

\begin{tabular}{|c|c|c|c|}
\hline Pertanyaan & Item & Frekuensi & Persentase \\
\hline \multirow{5}{*}{$\begin{array}{l}\text { 11. Saya turut } \\
\text { menjawab atau } \\
\text { memberi } \\
\text { tanggapan ketika } \\
\text { rekan kerja } \\
\text { bertanya atau } \\
\text { ketika berdiskusi } \\
\text { melalui Whatsapp }\end{array}$} & Setuju & 32 & $64,00 \%$ \\
\hline & $\begin{array}{l}\text { Sangat } \\
\text { Setuju }\end{array}$ & 15 & $30,00 \%$ \\
\hline & $\begin{array}{l}\text { Tidak } \\
\text { Setuju }\end{array}$ & 0 & $0,00 \%$ \\
\hline & $\begin{array}{l}\text { Sangat } \\
\text { Tidak } \\
\text { Setuju } \\
\end{array}$ & 1 & $2,00 \%$ \\
\hline & Netral & 2 & $4,00 \%$ \\
\hline \multicolumn{2}{|c|}{ Efektif } & 50 & $100,00 \%$ \\
\hline
\end{tabular}

Sumber: Data peneliti Kuesioner nomor 11

Pernyataan "Saya turut menjawab atau memberi tanggapan ketika rekan kerja bertanya atau ketika berdiskusi melalui Whatsapp" didapatkan data: 32 responden menjawab setuju dengan persentase $64,00 \%, 15$ responden menjawab sangat setuju dengan persentase $30,00 \%$, tidak ada responden yang menjawab pada pilihan jawaban tidak setuju sehingga presentasenya $0,00 \%, 1$ responden menjawab sangat tidak setuju dengan persentase $2,00 \%, 2$ responden menjawab netral dengan persentase $4,00 \%$. Dari pernyataan kuesioner nomor 11, mendapatkan hasil 50 responden yang menjawab dengan persentase $100 \%$.

Skor rata-rata:

$$
\begin{aligned}
X_{(11)} & =\frac{(15 \times 5)+(32 \times 4)+(2 \times 3)+(0 \times 2)+(1 \times 1)}{50} \\
& =4,2
\end{aligned}
$$


Hasil yang didapat dari kuesioner nomor 11 ialah 4,2 yang artinya dapat disimpulkan bahwa pada elemen kuesioner nomor 11 tersebut, yaitu pada tingkat Peran aktif pengguna saat berdiskusi di aplikasi whatsapp dapat disimpulkan Efektif.

\section{Pengaruh Aplikasi Whatsapp Dalam Membantu Mempermudah Jalannya Diskusi Kerja}

Tabel 12. Pengaruh aplikasi whatsapp dalam membantu mempermudah jalannya diskusi kerja

\begin{tabular}{|c|c|c|c|}
\hline Pertanyaan & Item & Frekuensi & Persentase \\
\hline \multirow{5}{*}{$\begin{array}{l}12 . \text { Whatsapp } \\
\text { berpengaruh dalam } \\
\text { membantu } \\
\text { mempermudah } \\
\text { jalannya diskusi } \\
\text { kerja }\end{array}$} & Setuju & 28 & $56,00 \%$ \\
\hline & \begin{tabular}{|l|} 
Sangat \\
Setuju
\end{tabular} & 20 & $40,00 \%$ \\
\hline & \begin{tabular}{|l|} 
Tidak \\
Setuju \\
\end{tabular} & 0 & $0,00 \%$ \\
\hline & $\begin{array}{l}\text { Sangat } \\
\text { Tidak } \\
\text { Setuju } \\
\end{array}$ & 0 & $0,00 \%$ \\
\hline & Netral & 2 & $4,00 \%$ \\
\hline \multicolumn{2}{|c|}{ Sangat Efektif } & 50 & $100,00 \%$ \\
\hline
\end{tabular}

Sumber: Data peneliti Kuesioner nomor 12

Pernyataan "Whatsapp berpengaruh dalam membantu mempermudah jalannya diskusi kerja" didapatkan data: 28 responden menjawab setuju dengan persentase 56,00\%, 20 responden menjawab sangat setuju dengan persentase $40,00 \%$, tidak ada responden yang menjawab pada pilihan jawaban tidak setuju dan sangat tidak setuju sehingga persentasenya $0,00 \%, 2$ responden menjawab netral dengan persentase 4,00\%. Dari pernyataan kuesioner nomor 12, mendapatkan hasil 50 responden yang menjawab dengan 
persentase $100 \%$. Skor rata-rata:

$$
\begin{aligned}
X_{(12)} & =\frac{(20 \times 5)+(28 \times 4)+(2 \times 3)+(0 \times 2)+(0 \times 1)}{50} \\
& =4,36
\end{aligned}
$$

Hasil yang didapat dari kuesioner nomor 12 ialah 4,36 yang artinya dapat disimpulkan bahwa pada elemen kuesioner nomor 12 tersebut, yaitu pada tingkat pengaruh aplikasi whatsapp dalam membantu mempermudah jalannya diskusi kerja dapat disimpulkan Sangat Efektif.

\section{Kemudahan Aplikasi whatsapp untuk bertukar informasi}

Tabel 13. Aplikasi whatsapp mempermudah bertukar

\begin{tabular}{|c|c|c|c|}
\hline Pertanyaan & Item & Frekuensi & Persentase \\
\hline \multirow{5}{*}{$\begin{array}{l}\text { 13. Whatapp } \\
\text { mempermudah } \\
\text { dalam bertukar } \\
\text { informasi perihal } \\
\text { urusan kerja }\end{array}$} & Setuju & 32 & $64,00 \%$ \\
\hline & $\begin{array}{l}\text { Sangat } \\
\text { Setuju }\end{array}$ & 18 & $36,00 \%$ \\
\hline & $\begin{array}{l}\text { Tidak } \\
\text { Setuju }\end{array}$ & 0 & $0,00 \%$ \\
\hline & $\begin{array}{l}\text { Sangat } \\
\text { Tidak } \\
\text { Setuju }\end{array}$ & 0 & $0,00 \%$ \\
\hline & Netral & 0 & $0,00 \%$ \\
\hline \multicolumn{2}{|c|}{ Sangat Efektif } & 50 & $100,00 \%$ \\
\hline
\end{tabular}
informasi

Sumber: Data peneliti Kuesioner nomor 13

Pernyataan "Whatapp mempermudah dalam bertukar informasi perihal urusan kerja" didapatkan data: 32 responden menjawab setuju dengan persentase 64,00\%, 18 responden menjawab sangat setuju dengan persentase $36,00 \%$, dan tidak ada responden yang memilih pada pilihan jawaban tidak setuju, sangat tidak setuju dan netral, sehingga persentasenya 0,00\%. Dari pernyataan kuesioner nomor 13, mendapatkan 
hasil 50 responden yang menjawab dengan persentase $100 \%$.

Skor rata-rata:

$$
\begin{aligned}
X_{(13)} & =\frac{(18 \times 5)+(32 \times 4)+(0 \times 3)+(0 \times 2)+(0 \times 1)}{50} \\
& =4,36
\end{aligned}
$$

Hasil yang didapat dari kuesioner nomor 13 ialah 4,36 yang artinya dapat disimpulkan bahwa pada elemen kuesioner nomor 13 tersebut, yaitu pada tingkat Aplikasi whatsapp mempermudah bertukar informasi perihal urusan kerja dapat disimpulkan Sangat Efektif.

\section{KEPUASAN}

\section{Aplikasi Whatsapp Membantu Memenuhi Kebutuhan}

\section{Informasi}

Tabel 14. Aplikasi whatsapp membantu memenuhi

\begin{tabular}{|c|c|c|c|}
\hline Pertanyaan & Item & Frekuensi & Persentase \\
\hline \multirow{5}{*}{$\begin{array}{l}14 . \\
\text { Whatsapp } \\
\text { membantu } \\
\text { memenuhi } \\
\text { kebutuhan } \\
\text { informasi }\end{array}$} & Setuju & 30 & $60,00 \%$ \\
\hline & $\begin{array}{l}\text { Sangat } \\
\text { Setuju }\end{array}$ & 20 & $40,00 \%$ \\
\hline & $\begin{array}{l}\text { Tidak } \\
\text { Setuju }\end{array}$ & 0 & $0,00 \%$ \\
\hline & $\begin{array}{l}\text { Sangat } \\
\text { Tidak } \\
\text { Setuju }\end{array}$ & 0 & $0,00 \%$ \\
\hline & Netral & 0 & $0,00 \%$ \\
\hline \multicolumn{2}{|c|}{ Sangat Efektif } & 50 & $100,00 \%$ \\
\hline
\end{tabular}
kebutuhan informasi

Sumber: Data peneliti Kuesioner nomor 14

Pernyataan "Whatsapp membantu memenuhi kebutuhan informasi" didapatkan data: 30 responden menjawab setuju dengan persentase $60,00 \%, 20$ responden 
menjawab sangat setuju dengan persentase $40,00 \%$, dan tidak ada responden yang memilih pada pilihan jawaban tidak setuju, sangat tidak setuju dan netral, sehingga persentasenya 0,00\%. Dari pernyataan kuesioner nomor 14, mendapatkan hasil 50 responden yang menjawab dengan persentase $100 \%$. Skor rata-rata:

$$
\begin{aligned}
X_{(14)} & =\frac{(20 \times 5)+(30 \times 4)+(0 \times 3)+(0 \times 2)+(0 \times 1)}{50} \\
& =4,4
\end{aligned}
$$

Hasil yang didapat dari kuesioner nomor 14 ialah 4,4 yang artinya dapat disimpulkan bahwa pada elemen kuesioner nomor 14 tersebut, yaitu pada tingkat Aplikasi whatsapp membantu memenuhi kebutuhan informasi dapat disimpulkan Sangat Efektif.

\section{KEPUASAN APLIKASI WHATSAPP MEMBANTU DALAM URUSAN KERJA}

Tabel 15. Aplikasi whatsapp membantu dalam urusan kerja

\begin{tabular}{|l|c|c|c|}
\hline \multicolumn{1}{|c|}{ Pertanyaan } & Item & Frekuensi & Persentase \\
\hline \multirow{2}{*}{$\begin{array}{l}\text { 15. Whatsapp } \\
\text { membantu } \\
\text { dalam urusan } \\
\text { kerja }\end{array}$} & Setuju & 28 & $56,00 \%$ \\
\cline { 2 - 4 } & $\begin{array}{l}\text { Sangat } \\
\text { Setuju }\end{array}$ & 21 & $\begin{array}{l}\text { Tidak } \\
\text { Setuju }\end{array}$ \\
\cline { 2 - 4 } & $\begin{array}{l}\text { Sangat } \\
\text { Tidak } \\
\text { Setuju }\end{array}$ & 0 & $0,00 \%$ \\
\cline { 2 - 4 } & Netral & 1 & $0,00 \%$ \\
\hline \multicolumn{2}{|c|}{ Sangat Efektif } & 50 & $2,00 \%$ \\
\hline
\end{tabular}

Sumber: Data peneliti Kuesioner nomor 15 
Pernyataan "Whatsapp membantu dalam urusan kerja" didapatkan data: 28 responden menjawab setuju dengan persentase $56,00 \%, 21$ responden menjawab sangat setuju dengan persentase $42,00 \%$, tidak ada responden yang memilih pada pilihan jawaban tidak setuju dan sangat tidak setuju, sebanyak 1 responden menjawab netral dengan persentase 2,00\%. Dari pernyataan kuesioner nomor 15, mendapatkan hasil 50 responden yang menjawab dengan persentase $100 \%$. Skor rata-rata:

$$
\begin{aligned}
X_{(15)} & =\frac{(21 \times 5)+(28 \times 4)+(1 \times 3)+(0 \times 2)+(0 \times 1)}{50} \\
& =4,4
\end{aligned}
$$

Hasil yang didapat dari kuesioner nomor 15 ialah 4,4 yang artinya dapat disimpulkan bahwa pada elemen kuesioner nomor 15 tersebut, yaitu pada tingkat Aplikasi Whatsapp membantu dalam urusan kerja dapat disimpulkan Sangat Efektif.

\section{Kepuasan Terhadap Fitur dan Pelayanan Dari Aplikasi Whatsapp}

Tabel 16. Kepuasan terhadap fitur dan pelayanan dari aplikasi whatsapp

\begin{tabular}{|c|l|c|c|}
\hline \multicolumn{1}{|c|}{ Pertanyaan } & Item & Frekuensi & Persentase \\
\hline \multirow{4}{*}{$\begin{array}{l}\text { 16. Saya merasa } \\
\text { puas dengan fitur } \\
\text { dan pelayanan dari } \\
\text { Whatsapp }\end{array}$} & Setuju & 29 & $58,00 \%$ \\
\cline { 2 - 4 } & $\begin{array}{l}\text { Sangat } \\
\text { Setuju }\end{array}$ & 18 & $36,00 \%$ \\
\cline { 2 - 4 } & $\begin{array}{l}\text { Tidak } \\
\text { Setuju }\end{array}$ & 0 & $0,00 \%$ \\
\cline { 2 - 4 } & $\begin{array}{l}\text { Sangat } \\
\text { Tidak } \\
\text { Setuju }\end{array}$ & 0 & $0,00 \%$ \\
\hline
\end{tabular}




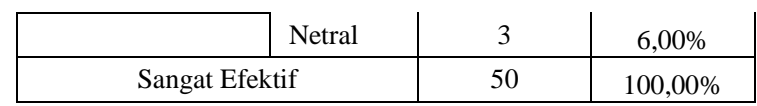

Sumber: Data peneliti Kuesioner nomor 16

Pernyataan "Saya merasa puas dengan fitur dan pelayanan dari Whatsapp" didapatkan data: 29 responden menjawab setuju dengan persentase 58,00\%, 18 responden menjawab sangat setuju dengan persentase $36,00 \%$, tidak ada responden yang memilih pada pilihan jawaban tidak setuju dan sangat tidak setuju, sebanyak 3 responden menjawab netral dengan persentase 6,00\%. Dari pernyataan kuesioner nomor 16, mendapatkan hasil 50 responden yang menjawab dengan persentase $100 \%$.

Skor rata-rata:

$$
\begin{aligned}
X_{(16)} & =\frac{(18 \times 5)+(29 \times 4)+(3 \times 3)+(0 \times 2)+(0 \times 1)}{50} \\
& =4,3
\end{aligned}
$$

Hasil yang didapat dari kuesioner nomor 16 ialah 4,3 yang artinya dapat disimpulkan bahwa pada elemen kuesioner nomor 16 tersebut, yaitu pada tingkat Kepuasan pengguna terhadap fitur dan pelayanan dari aplikasi whatsapp dapat disimpulkan Sangat Efektif.

Efektivitas aplikasi whatsapp sebagai tempat diskusi urusan kerja

Tabel 17. Efektivitas aplikasi whatsapp sebagai tempat diskusi urusan kerja

\begin{tabular}{|l|l|l|l|}
\hline Pertanyaan & Item & Frekuensi & Persentase \\
\hline \multirow{2}{*}{$\begin{array}{l}\text { 17. Whatsapp } \\
\text { efektiv }\end{array}$} & Setuju & 38 & $76,00 \%$ \\
\cline { 2 - 4 } & Sangat Setuju & 11 & $22,00 \%$ \\
\hline
\end{tabular}




\begin{tabular}{|c|c|c|c|c|}
\hline \multirow{3}{*}{\multicolumn{2}{|c|}{\begin{tabular}{ll}
\multicolumn{2}{l}{ digunakan } \\
sebagai & tempat \\
diskusi & urusan \\
kerja &
\end{tabular}}} & Tidak Setuju & \multirow{2}{*}{$\frac{0}{0}$} & \multirow{2}{*}{$\begin{array}{l}0,00 \% \\
0,00 \%\end{array}$} \\
\hline & & $\begin{array}{ll}\text { Sangat } & \text { Tidak } \\
\text { Setuju } & \end{array}$ & & \\
\hline & & Netral & 1 & $2,00 \%$ \\
\hline \multicolumn{3}{|l|}{ Efektif } & 50 & $100,00 \%$ \\
\hline
\end{tabular}

Sumber: Data peneliti Kuesioner nomor 17

Pernyataan "Whatsapp efektiv digunakan sebagai tempat diskusi urusan kerja" didapatkan data: 38 responden menjawab setuju dengan persentase $76,00 \%, 11$ responden menjawab sangat setuju dengan persentase $22,00 \%$, tidak ada responden yang memilih pada pilihan jawaban tidak setuju dan sangat tidak setuju, sebanyak 1 responden menjawab netral dengan persentase 2,00\% . Dari pernyataan kuesioner nomor 17, mendapatkan hasil 50 responden yang menjawab dengan persentase $100 \%$.

Skor rata-rata:

$$
\begin{aligned}
X_{(17)} & =\frac{(11 \times 5)+(38 \times 4)+(1 \times 3)+(0 \times 2)+(0 \times 1)}{50} \\
& =4,2
\end{aligned}
$$

Hasil yang didapat dari kuesioner nomor 17 ialah 4,2 yang artinya dapat disimpulkan bahwa pada elemen kuesioner nomor 17 tersebut, yaitu pada tingkat Efektivitas aplikasi whatsapp sebagai tempat diskusi urusan kerja dapat disimpulkan Efektif.

Kepuasan Pengguna Dalam Berdiskusi Menggunakan Aplikasi Whatsapp

Tabel 18. Kepuasan pengguna dalam berdiskusi 
menggunakan aplikasi whatsapp

\begin{tabular}{|c|c|c|c|}
\hline Pertanyaan & Item & Frekuensi & Persentase \\
\hline \multirow{5}{*}{$\begin{array}{l}\text { 18. Saya } \\
\text { mendapatkan } \\
\text { kepuasan (dalam } \\
\text { berdiskusi atau } \\
\text { bertukar } \\
\text { informasi) } \\
\text { menggunakan } \\
\text { Whatsapp }\end{array}$} & Setuju & 35 & $70,00 \%$ \\
\hline & $\begin{array}{c}\text { Sangat } \\
\text { Setuju }\end{array}$ & 14 & $28,00 \%$ \\
\hline & $\begin{array}{l}\text { Tidak } \\
\text { Setuju }\end{array}$ & 0 & $0,00 \%$ \\
\hline & $\begin{array}{l}\text { Sangat } \\
\text { Tidak } \\
\text { Setuju }\end{array}$ & 0 & $0,00 \%$ \\
\hline & Netral & 1 & $2,00 \%$ \\
\hline Sangat & tif & 50 & $100,00 \%$ \\
\hline
\end{tabular}

Sumber: Data peneliti Kuesioner nomor 18

Pernyataan "Saya mendapatkan kepuasan (dalam berdiskusi atau bertukar informasi) menggunakan Whatsapp" didapatkan data: 35 responden menjawab setuju dengan persentase $70,00 \%, 14$ responden menjawab sangat setuju dengan persentase $28,00 \%$, tidak ada responden yang memilih pada pilihan jawaban tidak setuju dan sangat tidak setuju, sebanyak 1 responden menjawab netral dengan persentase 2,00\%. Dari pernyataan kuesioner nomor 18, mendapatkan hasil 50 responden yang menjawab dengan persentase $100 \%$. Skor rata-rata:

$$
\begin{aligned}
X_{(18)} & =\frac{(14 \times 5)+(35 \times 4)+(1 \times 3)+(0 \times 2)+(0 \times 1)}{50} \\
& =4,26
\end{aligned}
$$

Hasil yang didapat dari kuesioner nomor 18 ialah 4,26 yang artinya dapat disimpulkan bahwa pada elemen kuesioner nomor 18 tersebut, yaitu pada tingkat Kepuasan pengguna dalam bertukar informasi atau berdiskusi menggunakan aplikasi whatsapp dapat disimpulkan Sangat Efektif. 


\section{Efektivitas Aplikasi Whatsapp Sebagai Media Komunikasi}

Tabel 19. Efektivitas aplikasi whatsapp sebagai media komunikasi

\begin{tabular}{|c|l|c|c|}
\hline Pertanyaan & \multicolumn{1}{|c|}{ Item } & Frekuensi & Persentase \\
\hline \multirow{4}{*}{$\begin{array}{l}\text { 19. Whatsapp efektif } \\
\text { digunakan sebagai } \\
\text { media komunikasi }\end{array}$} & Setuju & 32 & $64,00 \%$ \\
\cline { 2 - 4 } & Sangat Setuju & 18 & $36,00 \%$ \\
\cline { 2 - 4 } & Tidak Setuju & 0 & $0,00 \%$ \\
\cline { 2 - 4 } & $\begin{array}{l}\text { Sangat Tidak } \\
\text { Setuju }\end{array}$ & 0 & $0,00 \%$ \\
\cline { 2 - 4 } & Netral & 0 & $0,00 \%$ \\
\hline \multicolumn{2}{|c|}{ Sangat Efektif } & 50 & $100,00 \%$ \\
\hline
\end{tabular}

Sumber: Data peneliti Kuesioner nomor 19

Pernyataan "Whatsapp efektiv digunakan sebagai media komunikasi" didapatkan data: 32 responden menjawab setuju dengan persentase $64,00 \%, 18$ responden menjawab sangat setuju dengan persentase $36,00 \%$, dan tidak ada responden yang memilih pada pilihan jawaban tidak setuju, sangat tidak setuju dan netral, sehingga persentasenya $0,00 \%$. Dari pernyataan kuesioner nomor 19, mendapatkan hasil 50 responden yang menjawab dengan persentase $100 \%$. Skor rata-rata:

$$
\begin{aligned}
X_{(19)} & =\frac{(18 \times 5)+(32 \times 4)+(0 \times 3)+(0 \times 2)+(0 \times 1)}{50} \\
& =4,36
\end{aligned}
$$

Hasil yang didapat dari kuesioner nomor 19 ialah 4,36 yang artinya dapat disimpulkan bahwa pada elemen kuesioner nomor 19 tersebut, yaitu pada tingkat Efektivitas aplikasi whatsapp sebagai media komunikasi dapat disimpulkan 
Sangat Efektif.

\section{Whatsapp Sebagai Media Pendukung Meningkatkan Kinerja}

Tabel 20. Whatsapp sebagai media pendukung meningkatkan kinerja

\begin{tabular}{|l|c|c|c|}
\hline \multicolumn{1}{|l|}{ Pertanyaan } & Item & Frekuensi & Persentase \\
\hline \multirow{2}{*}{$\begin{array}{l}\text { 20. Whatsapp } \\
\text { sebagai media } \\
\text { pendukung } \\
\text { meningkatkan } \\
\text { kinerja }\end{array}$} & Setuju & 25 & $50,00 \%$ \\
\cline { 2 - 4 } & $\begin{array}{c}\text { Sangat } \\
\text { Setuju }\end{array}$ & 22 & $44,00 \%$ \\
\cline { 2 - 4 } & $\begin{array}{c}\text { Tidak } \\
\text { Setuju }\end{array}$ & 1 & $2,00 \%$ \\
\cline { 2 - 4 } & $\begin{array}{c}\text { Sangat } \\
\text { Tidak } \\
\text { Setuju }\end{array}$ & 0 & $0,00 \%$ \\
\cline { 2 - 4 } & Netral & 2 & $4,00 \%$ \\
\hline \multicolumn{2}{|c|}{ Sangat Efektif } & 50 & $100,00 \%$ \\
\hline
\end{tabular}

Sumber: Data peneliti Kuesioner nomor 20

Pernyataan "Whatsapp sebagai media pendukung meningkatkan kinerja" didapatkan data: 25 responden menjawab setuju dengan persentase 50,00\%, 22 responden menjawab sangat setuju dengan persentase $44,00 \%, 1$ responden menjawab tidak setuju dengan persentase $2,00 \%$, tidak ada responden yang memilih pada pilihan jawaban sangat tidak setuju sehingga persentasenya $0,00 \%, 2$ responden menajwab netral dengan persentase $4,00 \%$. Dari pernyataan kuesioner nomor 20, mendapatkan hasil 50 responden yang menjawab dengan persentase 100\%. Skor rata-rata:

$$
\begin{aligned}
X_{(20)} & =\frac{(22 \times 5)+(25 \times 4)+(2 \times 3)+(1 \times 2)+(0 \times 1)}{50} \\
& =4,36
\end{aligned}
$$


Hasil yang didapat dari kuesioner nomor 20 ialah 4,36 yang artinya dapat disimpulkan bahwa pada elemen kuesioner nomor 20 tersebut, yaitu pada tingkat aplikasi whatsapp sebagai media pendukung meningkatkan kinerja dapat disimpulkan Sangat Efektif.

\section{KESIMPULAN DAN SARAN}

Berdasarkan pembahasan hasil penelitian yang telah dilakukan kepada karyawan PT. Flexindo Mandiri Utama dengan jumlah responden sebanyak 50 orang terhadap Efektivitas pemanfaatan aplikasi whatsapp sebagai media komunikasi penunjang kinerja di kalangan karyawan PT. Flexindo yang diukur menggunakan 3 dimensi, yaitu Intensitas, Komunikasi, dan Kepuasan maka telah menghasilkan skor rata-rata yang bisa dilihat dalam skala penilaian.

dari 6 item hasil skor rata-rata tersebut, dapat dijumlahkan untuk mendapatkan skor rata-rata dalam dimensi intensitas ialah sebagai berikut:

$$
\begin{aligned}
\bar{X} & =\frac{4,42+4,22+4,38+3,9+4,34+4,44}{6} \\
& =4,2833
\end{aligned}
$$

Dapat disimpulkan bahwa pada dimensi Intensitas ini, dari hasil rata-rata 6 pernyataan tersebut termasuk Sangat Efektif.

Dari 7 item hasil skor rata-rata, dapat dijumlahkan untuk mendapatkan skor rata-rata dalam dimensi komunikasi ialah sebagai berikut: 


$$
\begin{aligned}
\bar{X} & =\frac{4,36+4,5+4,34+4,32+4,2+4,36+4,36}{7} \\
& =4,3485
\end{aligned}
$$

Dapat disimpulkan bahwa pada dimensi Komunikasi ini, dari hasil rata-rata 7 pernyataan tersebut termasuk Sangat Efektif.

Dari 7 item hasil skor rata-rata, dapat dijumlahkan untuk mendapatkan skor rata-rata dalam dimensi kepuasan ialah sebagai berikut:

$$
\begin{aligned}
\bar{X} & =\frac{4,4+4,4+4,3+4,2+4,26+4,36+4,36}{7} \\
& =4,3257
\end{aligned}
$$

Dapat disimpulkan bahwa pada dimensi Kepuasan ini, dari hasil rata-rata 7 pernyataan tersebut termasuk Sangat Efektif.

Dapat disimpulkan dari analisis dan ulasan diatas bahwa Efektivitas pemanfaatan aplikasi whatsapp sebagai media komunikasi penunjang kinerja di kalangan karyawan PT. Flexindo adalah Sangat Efektif.

\section{DAFTAR PUSTAKA}

Andjani, A. Ratnamulyani \& Kusumadinata. (2018). Penggunaan Media Komunikasi Whtasapp terhadap efektivitas kinerja karyawan. Jurnal Komunikatio, volume 4 No. 2.

Baskara, T., \& Fajar Rizki, M. (2019). Proses Publikasi Humas Badan Nasional Pengelola Perbatasan Pada Akun Media Sosial Instagram. CoverAge: Journal of Strategic Communication, $10(1)$ 19-26. https://doi.org/10.35814/coverage.v10i1.1229 
Noor, Juliansyah. (2012). Metodologi Penelitian. Jakarta: Kencana Nur Hasanah. (2020). Pengaruh Pengunaan Media Audio Visual Terhadap Hasil Belajar Siswa Pada Pembelajaran IPA Kelas IV di SDS Nurul Ikhlas. Skripsi S1 Program Studi Kependidikan Islam Sekolah Tinggi Agama Islam (STAI). Publisistik Thawalib Jakarta, 1-103.

Parinduri, T.H. (2019). Pengaruh Penggunaan media sosial Whatsapp terhadap Kinerja Pegawai pada Kantor Kesehatan Pelabuhan Kelas I Medan. Tesis S-2. Universitas Muhammdyah Sumatra Utara.

Raharti. (2019). Whatsapp Media Komunikasi Efektif Masa Kini (Studi Kasus Pada Layanan Jasa Informasi Ilmiah di Kawasan Puspitek). VISI PUSTAKA Vol. 21, No. 2, Agustus 2019, 147-156.

SME (2020). Onestop Telco Solution. http://www.smartme.co.id.

Diakses 22 Oktober 2020)

Sugianto, Arifin., dkk. Pengaruh Komunikasi Melalui Grup Whatsapp Untuk Meningkatkan Kinerja Karyawan di Hotel Grandhika Medan. Jurnal Lensa Mutiara Komunikasi ISSN:2579-8332, 33-42.

Sugiarsih Duki Saputri, R. (2019). Pengaruh Kualitas Pelayanan dan Harga Terhadap Loyalitas Pelanggan Grab Semarang. CoverAge: Journal of Strategic Communication, 10(1), 46-

53. https://doi.org/10.35814/coverage.v10i1.1232

Sugiyono. (2008). Metode Penelitian Kuantitatif, Kualitatif dan 
$R \& D$. Bandung: Alfabeta

Trisnani. (2017). Pemanfaatan Whatsapp Sebagai Media Komunikasi dan Kepuasan Dalam Penyampaian Pesan dikalangan Tokoh Masyarakat. JURNAL KOMUNIKASI, MEDIA DAN INFORMATIKA, Volume 6 Nomor 3 / November 2017, 1-12.

Pertiwi. (2020). Whtasapp tembus 2 Milia Pengguna.https://tekno.kompas.com/read/2020/11/01/1603 0007/whatsapp-saat-ini-2-miliar-pengguna-100-miliarpesan-per-hari. diakses pada 12 Desember 2020 pukul 22:30 WIB 